\title{
Glycated Haemoglobin Levels and Its Effect on Outcomes in Cardiac Surgery
}

\author{
Daniyal Matin Ansari ${ }^{1}$; Tinotenda Harahwa, BSc ${ }^{1}$; Eyad Abuelgasim, BSc²; Amer Harky, ${ }^{3,4}$, MRCS, MSc
}

DOI: 10.21470/1678-9741-2020-0188

\begin{abstract}
There remains a significant paucity of information evaluating the effect of glycated $\mathrm{HbA} 1 \mathrm{c}$ levels and its theorized effect on mortality and morbidity rates following cardiac surgery. Diabetes is a very common comorbidity in patients undergoing open heart surgery, as there is a shift in patient characteristics and greater risk. Currently, there is no clear consensus that an increase in $\mathrm{HbA} 1 \mathrm{c}$ level is associated with increased perioperative mortality rate. However, the reported literature is more commonly able to demonstrate that elevated $\mathrm{HbA1c}$ levels is
\end{abstract}

\begin{abstract}
associated with increased rates of wound infection, cardiovascular events and renal failure, and thus, higher post-operative morbidities. This review aims to examine and synthesis the evidence behind each of the morbidities and mortalities associated with open heart surgery and the impact of high HbA1c on the reported outcomes.

Keywords: Glycated Hemoglobin A. Comorbidity. Diabetes Mellitus. Morbidity. Cardiac Surgical Procedures. Renal Insufficiency. Wound Infection. Cardiovascular Diseases.
\end{abstract}

\begin{tabular}{|c|c|c|c|}
\hline \multicolumn{4}{|c|}{ Abbreviations, acronyms \& symbols } \\
\hline ADA & = American Diabetes Association & LOS & $=$ Length of stay \\
\hline $\mathrm{AF}$ & $=$ Atrial fibrillation & MI & = Myocardial infarction \\
\hline AGEs & $=$ Advanced glycation end-products & OCTOPUS & $=$ Optimising Cardiac Surgery outcomes in People \\
\hline CABG & $=$ Coronary artery bypass grafting & & with diabetes \\
\hline $\mathrm{Cl}$ & $=$ Confidence interval & OPCAB & $=$ Off-pump coronary artery bypass \\
\hline CMM & $=$ Composite morbidity-mortality & $\mathrm{PCl}$ & $=$ Percutaneous coronary intervention \\
\hline CVA & $=$ Cerebrovascular accident & TIA & $=$ Transient ischemic attack \\
\hline DM & $=$ Diabetes mellitus & WHO & $=$ World Health Organization \\
\hline HbA1c & = Glycated haemoglobin & WMD & $=$ Weighted mean difference \\
\hline HR & $=$ Hazard ratio & & \\
\hline
\end{tabular}

\section{INTRODUCTION}

HbA1c levels refer to the levels of glycated haemoglobin present in the blood. These levels are used to represent the average plasma glucose of a patient over the previous 8 to 12 weeks ${ }^{[1]}$. HbA1c levels are commonly used to diagnose diabetes and are an indicator for the likelihood of patients with diabetes to develop diabetic complications. More recently, there has been a substantial amount of interest in using $\mathrm{HbA1c}$ levels as a screening test for those at high risk of developing diabetes ${ }^{[2]}$.

\footnotetext{
'St. George's Hospital Medical School, London, United Kingdom.

2 Faculty of Medicine, Imperial College London, London, United Kingdom.

3Department of Cardiothoracic Surgery, Liverpool Heart and Chest Hospital, Liverpool, United Kingdom.

${ }^{4}$ Liverpool Centre for Cardiovascular Science, University of Liverpool and Liverpool Heart and Chest Hospital, Liverpool, United Kingdom.

This study was carried out at School of Medicine, St George's Hospital Medical School, London, United Kingdom.
}

It is believed that $\mathrm{HbA1c}$ levels are viewed as a risk factor for post-operative complications of cardiac surgery. Cardiac surgery can result in increased glycated haemoglobin levels, which are associated with increased morbidity and mortality rates. Despite this, some studies suggest that increased $\mathrm{HbA} 1 \mathrm{c}$ levels cannot be directly attributed as a cause of increased mortality and morbidity ${ }^{[3]}$. A recent meta-analysis of 7895 diabetic patients undergoing CABG surgery reported that higher $\mathrm{HbA1C}$ concentrations are frequently linked with the presence of other

Correspondence Address:

Amer Harky

(D) https://orcid.org/0000-0001-5507-5841

Department of Cardiothoracic Surgery, Liverpool Heart and Chest Hospital,

Liverpool, United Kingdom - Zip code: L14 3PE

E-mail: amer.harky@lhch.nhs.uk

Article received on April 22 $2^{\text {nd }}, 2020$. Article accepted on June $2^{\text {nd }}, 2020$. 
metabolic disorders, such as hypertension, dyslipidaemia and obesity, which are in fact the real problems causing an increased risk of poor clinical outcomes ${ }^{[3]}$.

However, a recent prospective, observational study of 7,565 inpatients showed that diabetes and elevated $\mathrm{HbA} 1 \mathrm{c}$ levels were independently associated with a higher risk of adverse outcomes after surgery ${ }^{[4]}$.

The whole process behind surgical procedures can place a great deal of physical stress on patients and thus impair glucose metabolism, therefore worsening the diabetes status. Those suffering from diabetes and chronic hyperglycaemia, determined by their HbA1c levels, may be at particular risk of suffering from perioperative morbidity from diabetes-related complications, such as wound infections and renal dysfunction ${ }^{[5,6]}$.

This review aims to examine and synthesis the evidence behind each of the morbidities and mortalities associated with open heart surgery and the impact of high $\mathrm{HbA} 1 \mathrm{c}$ on the reported outcomes.

\section{Literature Search}

A comprehensive literature search was done on PubMed, SCOPUS, Embase, Cochrane, Google Scholar and Ovid databases to identify the articles that discussed $\mathrm{HbA} 1 \mathrm{C}$ and its implications on perioperative cardiac surgery outcomes. The keywords used were 'HbA1c', 'Glycated haemoglobin', 'Cardiac surgery', 'Haemoglobin A', 'HbA1c and outcomes', 'Diabetes' and 'Diabetic correlation'. The search terms were used as keywords and in combination as MeSH terms to maximize the output from literature findings. A staged literature search was done, whereby a separate literature search was performed for each section of this article and all the relevant studies were identified and summarized separately. If a study is reporting on many aspects of the practice of $\mathrm{HbA1C}$, then the results have been shared between different parts of this review. The relevant articles are cited and referenced within each section separately. No limits were placed on publication time or language of the article.

\section{Pathophysiology of $\mathrm{HbA} 1 \mathrm{c}$}

Proteins are frequently glycated during various enzymatic reactions when the conditions are physiologically favourable. However, in the case of haemoglobin A, the glycation occurs by a nonenzymatic reaction between the condensation of glucose and the $\mathrm{N}$-terminal end of the $\beta$-chain of haemoglobin A, commonly lysine, forming a Schiff base (aldimine) ${ }^{[6]}$. The Schiff base may then undergo a rearrangement, converting

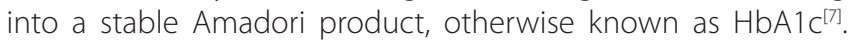
The formation of glycated haemoglobin is a routine part of the physiological function cycle. It was found that, as the average plasma glucose increases, so does the rate of this glycation reaction and the total quantity of $\mathrm{HbA} 1 \mathrm{c}$ produced in the plasma ${ }^{[8]}$. The longer hyperglycaemia occurs in blood, the more glucose binds to haemoglobin in red blood cells. This results in increased rates of production of glycated haemoglobin. Once a haemoglobin molecule is glycated, it remains that way and its Amadori arrangement is viewed as "nearly irreversible", according to a study by Higgins and Bunn ${ }^{[9]}$. As a result, this specific characteristic of haemoglobin is utilized as a biomarker, estimating average blood glucose levels in humans over the previous 2 to 3 months $^{[8]}$.

The glycation of haemoglobin results in the formation of advanced glycation end-products (AGEs). Alongside their formation is the accompanied release of free radicals and oxidants as side products from the Amadori rearrangement. This result in oxidative damage to cells and the extracellular matrix of the body tissue ${ }^{[10]}$. It is found that, additionally, the accumulation of these free radicals alters the erythrocyte membrane properties, leading to erythrocyte aggregation, increased blood viscosity and impaired blood flow ${ }^{[11]}$. This can result in shear stress, due to the thicker abrasive blood consistency, which affects the vascular endothelium and can result in a number of inflammatory and atherogenic events if the levels become excessive ${ }^{[12]}$. Following a consultation from the World Health Organization (WHO), it was concluded that HbA1c can be used as a viable diagnostic test for diabetes. This was as long as "stringent quality assurance tests are in place" and assays are kept consistent and standardised to their stated criteria, aligned to their internationally set reference values $^{[13]}$. It is also important that there are no conditions present that interfere with the accuracy of its measurement. An $\mathrm{HbA} 1 \mathrm{c}$ of $6.5 \%$ is recommended as the cut-off point for diagnosing diabetes, according to the guidelines set by the World Health Organization $^{[13]}$. A value $<6.5 \%$ does not exclude diabetes diagnosed using glucose tests ${ }^{[13]}$. According to the American Diabetes Association (ADA) 2020 Guidelines, the HbA1c value should be kept below $7 \%$ in all non-pregnant adult diabetics $(53 \mathrm{mmol} / \mathrm{mol})^{[14]}$. Values $>7 \%$ indicate an increased chance of progression to diabetic complications, especially microvascular ones. The HbA1c levels appear to be closely related to blood glucose levels and are resultantly affected by any forms of glycaemic control. An initially raised $\mathrm{HbA} 1 \mathrm{c}$ level has been found to progressively decrease in the weeks following the introduction of insulin and dietary therapy, with a tendency for these values to level out after approximately seven weeks of therapy ${ }^{[15]}$.

\section{HbA1c and Mortality Rates}

As the incidence of diabetes mellitus (DM) increases, the proportion of people with DM undergoing cardiac surgery has also increased ${ }^{[16]}$. There is a large body of evidence that has looked at the association between patient HbA1c levels and mortality following cardiac surgery. The evidence on the effect of $\mathrm{HbA1c}$ levels on mortality is contradictory, with some studies reporting that increased $\mathrm{HbA1c}$ levels are associated with increased mortality ${ }^{[17,18]}$. But by in large, most studies seem to show that increased $\mathrm{HbA} 1 \mathrm{c}$ is not predictive of increased mortality as a solo indicator ${ }^{[19-24]}$. The findings from all these studies are summarised in Table 1 and Table 2.

The study with the largest patient cohort looked at outcomes in 6,313 patients with type 2 DM who underwent CABG surgery between 2003 and 2013 ${ }^{[17]}$. The study found that HbA1c was associated with an increased risk of death in patients with an HbA1c level between 9.1 and 10.0\% (hazard ratio [HR] 1.26, 95\% $\mathrm{Cl}$ 1.04-1.53), and this risk was even greater in patients with $\mathrm{HbA1C}$ $>10.0 \%$ (HR 1.33, 95\% Cl 1.05-1.69). One study showed that 30-day 
mortality was significantly higher in patients with $\mathrm{HbA1c}$ $>6.5 \%$ compared to those with $\mathrm{Hb}$ lac $<6.5 \%$ (4.22\% vs. 3.07\%, $P=0.0035)$, however, following multivariable adjustment, this association was lost and there was no significant difference in the mortality rates ${ }^{[20]}$.

All of these studies, overall, demonstrate that increased $\mathrm{HbA} 1 \mathrm{c}$ increases mortality in cardiac surgery patients and all of them, with the exception of one, had large sample sizes, meaning they were all by in large sufficiently statistically powered to make their findings significant. However, all the aforementioned studies were retrospective in nature, meaning they were liable to biases inherent in the study design and the studies do not demonstrate causality.

The largest cohort study demonstrating that there is no relationship between $\mathrm{HbA} 1 \mathrm{c}$ levels and mortality looked at the outcomes in 6,393 patients undergoing cardiac surgery ${ }^{[21]}$. The study found that $\mathrm{HbA} 1 \mathrm{c}$ was not a significant predictor of postoperative mortality $(P=0.88)$. Further studies similarly showed that there was no significant difference in mortality following cardiac surgery according to $\mathrm{HbA} 1 \mathrm{c}$ levels, regardless of the HbA1c cut-off levels utilised ${ }^{[22,23]}$.

Overall, the evidence showing that there is no significant difference between higher $\mathrm{HbA1c}$ levels in the incidence of mortality outweighs the evidence showing that elevated $\mathrm{HbA1c}$ is associated with increased mortality, suggesting that $\mathrm{HbA1c}$ alone may not be predictive of mortality following cardiac surgery.

\section{HbA1c and Wound Infection}

A chronic state of impaired glucose metabolism has long been demonstrated to affect components of the immune system, thereby meaning that $\mathrm{HbA1c}$ may impact the rate of post-operative infections. Post-operative wound infection affects patient morbidity and hospital length of stay following cardiac surgery and hence it is important to analyse the relationship between $\mathrm{HbA} 1 \mathrm{c}$ levels and the infection rate. Some studies have shown that $\mathrm{HbA} 1 \mathrm{c}$ level has no effect on the rate of wound infection ${ }^{[22-26]}$. By contrast, there are studies that have demonstrated that elevated $\mathrm{HbA} 1 \mathrm{c}$ levels are associated with an increased rate of wound infection ${ }^{[18,20,27]}$. The main outcomes of these studies are summarised in Table 3 and Table 4.

Biskupski et al. ${ }^{[28]}$ analysed outcomes in 350 patients who were stratified into three groups according to $\mathrm{HbA} 1 \mathrm{c}$ levels: $<7.0 \%, 7.0-8.0 \%$, and $>8.0 \%$. The study found that there was no

Table 1. Summary of clinical outcomes in included studies that showed that the $\mathrm{HbA} 1 \mathrm{c}$ level is predictive of mortality.

\begin{tabular}{|c|c|c|c|c|}
\hline Study & Study design & $\begin{array}{l}\text { Single/ } \\
\text { Multi-centre }\end{array}$ & Sample size & Main outcomes \\
\hline \multirow{3}{*}{$\begin{array}{l}\text { Kuhl et al. }{ }^{[17]}, \\
2016\end{array}$} & \multirow{3}{*}{ Retrospective } & \multirow{3}{*}{$\begin{array}{l}\text { Multi-centre (across } \\
\text { Sweden) }\end{array}$} & \multirow{3}{*}{6,313 patients } & $\begin{array}{l}\text { - HbA1c associated with increased risk of } \\
\text { death in patients with HbA1c levels 9.1- } \\
\text { 10.0\% (HR 1.26, 95\% Cl 1.04-1.53) }\end{array}$ \\
\hline & & & & $\begin{array}{l}\text { - HbA1c associated with increased risk of } \\
\text { death in patients with } \mathrm{HbA1c}>10.0 \% \text { (HR } \\
1.33,95 \% \mathrm{Cl} 1.05-1.69)\end{array}$ \\
\hline & & & & $\begin{array}{l}\text { - Stepwise increased risk of death with } \\
\text { increasing HbA1 c: } 8.1-9.0 \% \text { (HR 1.17, 95\% Cl } \\
\text { 1.04-1.33), 9.1-10.0\% (HR 1.44,95\% Cl 1.22- } \\
\text { 1.70) and >10.0\% (HR 1.50, 95\% Cl 1.22-1.84) }\end{array}$ \\
\hline \multirow{2}{*}{$\begin{array}{l}\text { Halkos et al. }{ }^{[18]}, \\
2008\end{array}$} & \multirow[t]{2}{*}{ Retrospective } & \multirow[t]{2}{*}{ Single centre (USA) } & \multirow[t]{2}{*}{ 3,089 patients } & $\begin{array}{l}\text { - Elevated HbA1c predicted in-hospital } \\
\text { mortality after CABG (OR 1.40 per unit HbA1c } \\
\text { increase, 95\% Cl 1.06-1.86, P=0.019) }\end{array}$ \\
\hline & & & & $\begin{array}{l}\text { - HbA1c }>8.6 \% \text { associated with a 4-fold } \\
\text { increase in mortality }\end{array}$ \\
\hline \multirow{2}{*}{$\begin{array}{l}\text { Kim et al. }{ }^{[19]}, \\
2020\end{array}$} & \multirow[t]{2}{*}{ Retrospective } & \multirow{2}{*}{$\begin{array}{l}\text { Single centre (South } \\
\text { Korea) }\end{array}$} & \multirow[t]{2}{*}{703 patients } & $\begin{array}{l}\text { - Incidence of the composite post-operative } \\
\text { morbidity and mortality endpoint was } \\
\text { greater in patients with } \mathrm{HbA} 1 \mathrm{c} \geq 7.0 \% \text { when } \\
\text { compared to } \mathrm{HbA} 1 \mathrm{c}<7.0 \% \text { ( } 21 \% \text { vs. 15\%, } \\
P=0.041 \text { ) }\end{array}$ \\
\hline & & & & $\begin{array}{l}\text { - A greater pre-operative HbA1c } \geq 7.0 \% \text { was } \\
\text { independently associated with composite } \\
\text { mortality and morbidity endpoints (OR 1.60, } \\
95 \% \mathrm{Cl} 1.03-2.50, P=0.038 \text { ) }\end{array}$ \\
\hline
\end{tabular}

$\mathrm{CABG}=$ coronary artery bypass grafting; $\mathrm{Cl}=$ confidence interval; $\mathrm{HR}=$ hazard ratio; $\mathrm{OR}=$ odds ratio 
Table 2. Summary of clinical outcomes in included studies that showed that the HbA1c level had no effect on post-operative mortality.

\begin{tabular}{|c|c|c|c|c|}
\hline Study & Study design & $\begin{array}{c}\text { Single/ } \\
\text { Multi-centre }\end{array}$ & Sample size & Main outcomes \\
\hline $\begin{array}{l}\text { Narayan et al. }{ }^{[20]}, \\
2017\end{array}$ & Retrospective & $\begin{array}{l}\text { Single centre } \\
\text { (India) }\end{array}$ & 4,678 patients & $\begin{array}{l}\text { - } 30 \text {-day mortality was significantly } \\
\text { higher in patients with } \mathrm{HbA} 1 \mathrm{c} \geq 6.5 \% \\
\text { when compared to those with } \mathrm{HbA} 1 \mathrm{c} \\
<6.5 \%(4.22 \% \text { vs. } 3.07 \%, P=0.0035) \text {, but } \\
\text { in the multivariable analysis there was } \\
\text { no significant difference in mortality } \\
\text { (OR } 1.36,95 \%, \mathrm{Cl} 0.95-1.953, P=0.08)\end{array}$ \\
\hline $\begin{array}{l}\text { van den Boom et } \\
\text { al. }{ }^{[21]}, 2018\end{array}$ & Retrospective & $\begin{array}{l}\text { Single centre } \\
\text { (USA) }\end{array}$ & 6,393 patients & $\begin{array}{l}\text { - HbA1c was found to not be a } \\
\text { significant predictor of post-operative } \\
\text { mortality in cardiac surgery }(P=0.88)\end{array}$ \\
\hline \multirow[t]{2}{*}{$\begin{array}{l}\text { Tsuruta et al. }{ }^{[22]}, \\
2011\end{array}$} & \multirow[t]{2}{*}{ Prospective } & \multirow[t]{2}{*}{$\begin{array}{l}\text { Single centre } \\
\text { (Japan) }\end{array}$} & \multirow[t]{2}{*}{306 patients } & $\begin{array}{l}\text { - No significant difference in all-cause } \\
\text { mortality or cardiac mortality between } \\
\text { patients with } \mathrm{HbA} 1 \mathrm{c}<6.5 \%, 6.5-7.5 \% \\
\text { and } \geq 7.5 \% \text { (HR } 0.80,95 \% \mathrm{Cl} 0.49-1.23 \text {, } \\
P=0.26 \text { and } P=0.17 \text {, respectively) }\end{array}$ \\
\hline & & & & $\begin{array}{l}\text { - Multivariate analysis showed that } \\
\text { HbA1c did not predict mortality }\end{array}$ \\
\hline \multirow{2}{*}{$\begin{array}{l}\text { Ramadan et al. }{ }^{[23]}, \\
2018\end{array}$} & \multirow{2}{*}{ Prospective } & \multirow{2}{*}{$\begin{array}{l}\text { Single centre } \\
\text { (Egypt) }\end{array}$} & \multirow{2}{*}{80 patients } & $\begin{array}{l}\text { - There was no statistically significant } \\
\text { difference for in-hospital mortality } \\
\text { between patients with } \mathrm{HbA} 1 \mathrm{c} \leq 7.0 \% \\
\text { and } \mathrm{HbA} 1 \mathrm{c}>7.0 \% \text { (2.5\% vs. } 7.5 \% \\
P=0.608)\end{array}$ \\
\hline & & & & $\begin{array}{l}\text { - There was no statistically significant } \\
\text { difference for one-year mortality } \\
\text { between patients with HbA1c } \leq 7.0 \% \\
\text { and } \mathrm{HbA} 1 \mathrm{~b}>7.0 \% \text { (5.13\% vs. } 8.11 \% \text {, } \\
P=0.600 \text { ) }\end{array}$ \\
\hline 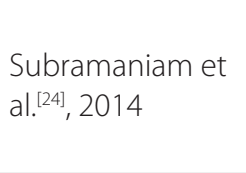 & Prospective & $\begin{array}{l}\text { Single centre } \\
\text { (Israel) }\end{array}$ & 1,461 patients & $\begin{array}{l}\text { - No statistically significant difference } \\
\text { in the incidence of death between } \\
\text { patients with HbA1c <6.5\% and with } \\
\mathrm{HbA} 1 \mathrm{c} \geq 6.5 \% \text { (3\% vs. } 2.6 \%, P=0.90)\end{array}$ \\
\hline \multirow{2}{*}{$\begin{array}{l}\text { Biskupski et al. }{ }^{[28]}, \\
2014\end{array}$} & \multirow[t]{2}{*}{ Retrospective } & \multirow{2}{*}{$\begin{array}{l}\text { Single centre } \\
\quad \text { (Poland) }\end{array}$} & \multirow[t]{2}{*}{350 patients } & $\begin{array}{l}\text { - There was no significant difference } \\
\text { in the incidence of death between } \\
\text { patients with HbA1c }<7.0 \% \text { compared } \\
\text { to HbA1c } 7.0-8.0 \% \text { (1.02\% vs. } 2.27 \% \text {, } \\
P=0.78 \text { ) }\end{array}$ \\
\hline & & & & $\begin{array}{l}\text { - There was no significant difference } \\
\text { in the incidence of death between } \\
\text { patients with } \mathrm{HbA} 1 \mathrm{c}<7.0 \% \text { and with } \\
\mathrm{HbA} 1 \mathrm{c}>8.0 \%(1.02 \% \text { vs. } 4.74 \%, P=0.20)\end{array}$ \\
\hline $\begin{array}{l}\text { Finger et al. }{ }^{[30]}, \\
2017\end{array}$ & Retrospective & $\begin{array}{l}\text { Single centre } \\
\text { (USA) }\end{array}$ & 531 patients+D21:D24D19:D24 & $\begin{array}{l}\text { - There was no statistically significant } \\
\text { difference in } 30 \text {-day mortality } \\
\text { between patients with HbA1c } \leq 7.0 \% \\
\text { or with } \mathrm{HbA} 1 \mathrm{c}>7.0 \% \text { ( } 2.74 \% \text { vs. } 3.51 \% \text {, } \\
P=0.670)\end{array}$ \\
\hline
\end{tabular}


Table 3. Summary of clinical outcomes in included studies that showed that the HbA1c level had no effect on post-operative wound infection.

\begin{tabular}{|c|c|c|c|c|}
\hline Study & Study design & $\begin{array}{c}\text { Single/ } \\
\text { Multi-centre }\end{array}$ & Sample size & Main outcomes \\
\hline \multirow{2}{*}{$\begin{array}{l}\text { Biskupski et al.[28], } \\
2014\end{array}$} & \multirow{2}{*}{ Retrospective } & \multirow{2}{*}{$\begin{array}{l}\text { Single centre } \\
\quad \text { (Poland) }\end{array}$} & \multirow{2}{*}{350 patients } & $\begin{array}{l}\text { - There was no significant difference in the } \\
\text { incidence of wound infection between } \\
\text { patients with HbA1c <7.0\% compared to } \\
\text { HbA1c } 7.0-8.0 \% \text { (1.53\% vs. 3.40\%, } P=0.57)\end{array}$ \\
\hline & & & & $\begin{array}{l}\text { - There was no significant difference in the } \\
\text { incidence of wound infection between } \\
\text { patients with HbA1c }<7.0 \% \text { and with HbA1c } \\
>8.0 \%(1.53 \% \text { vs. } 5.97 \%, P=0.13)\end{array}$ \\
\hline $\begin{array}{l}\text { Tsuruta et al. }{ }^{[22]}, \\
2011\end{array}$ & Prospective & Single centre (Japan) & 306 patients & $\begin{array}{l}\text { - There was no significant difference in the } \\
\text { frequency of mediastinitis between patients } \\
\text { with } \mathrm{HbA} 1 \mathrm{c}<6.5 \%, \mathrm{HbA} 1 \mathrm{c} 6.5-7.5 \% \text { and } \\
\mathrm{HbA} 1 \mathrm{c} \geq 7.5 \%(P=0.11)\end{array}$ \\
\hline $\begin{array}{l}\text { Ramadan et al. }{ }^{[23]}, \\
2018\end{array}$ & Prospective & Single centre (Egypt) & 80 patients & $\begin{array}{l}\text { - There was no statistically significant } \\
\text { difference in the incidence of deep sternal } \\
\text { wound infection between patients with } \\
\text { HbA1c } \leq 7.0 \% \text { and }>7.0 \% \text { (0 vs. } 5 \%, P=0.152)\end{array}$ \\
\hline \multirow[b]{2}{*}{$\begin{array}{l}\text { Göksedef et al. }{ }^{[29],} \\
2018\end{array}$} & \multirow[b]{2}{*}{ Prospective } & \multirow[b]{2}{*}{$\begin{array}{l}\text { Single centre } \\
\text { (Turkey) }\end{array}$} & \multirow[b]{2}{*}{150 patients } & $\begin{array}{l}\text { - HbA1c level was found to not affect the } \\
\text { short-term infectious complication rates }\end{array}$ \\
\hline & & & & $\begin{array}{l}\text { - There were no statistical differences between } \\
\text { patients with } \mathrm{HbA} 1 \mathrm{c}<7.0 \% \text { and } \mathrm{HbA} 1 \mathrm{c} \\
>7.0 \% \text { for non-sternal infection }(2.1 \% \text { vs. } \\
3.5 \%, P=0.744) \text { and for deep sternal wound } \\
\text { infection }(P=0.431)\end{array}$ \\
\hline
\end{tabular}

significant difference in the incidence of wound infection in the group with $\mathrm{HbA} 1 \mathrm{c}<7.0 \%$ when compared to those with $\mathrm{HbA} 1 \mathrm{c}$ $7.0-8.0 \%$ and to those with $\mathrm{HbA} 1 \mathrm{c}>8.0 \%$ (1.53\% vs. $3.40 \%$, $P=0.57$ and $1.53 \%$ vs. $5.97 \%, P=0.13$, respectively). In a study in which the primary outcome analysed was the incidence of wound infections, it was found that there was no statistically significant difference in the rate of all subset of wound infection in patients with $\mathrm{HbA} 1 \mathrm{c}<7.0 \%$ and in those with $\mathrm{HbA} 1 \mathrm{c}>7.0 \%$ $(P=0.431$ and $P=0.744$ for sternal and non-sternal infections, respectively) ${ }^{[29]}$.

By contrast, Gatti et al. ${ }^{[25]}$ specifically looked at whether $\mathrm{HbA1c}$ was a risk factor for sternal wound infection following CABG surgery in 2,130 patients and found that the mean baseline $\mathrm{HbA} 1 \mathrm{c}$ level was significantly higher in patients who had sternal wound infection ( $54 \pm 17 \mathrm{mmol} / \mathrm{mol}$ vs. $45 \pm 13 \mathrm{mmol} /$ mol; $P<0.0001)$. Logistic regression showed that the $\mathrm{HbA} 1 \mathrm{c}$ level was an independent risk factor for sternal wound infection (OR $1.04,95 \% \mathrm{Cl} 1.02-1.05, P<0.0001)$ with an $\mathrm{HbA} 1 \mathrm{c}$ level $>8.6 \%$ associated with the highest risk of sternal wound infection (OR $5.01,95 \% \mathrm{Cl} 2.47-10.15)$. Similar results were shown in a range of other studies that all showed that pre-operative elevated $\mathrm{HbA} 1 \mathrm{C}$ was associated with an increased incidence of both sternal and non-sternal wound infection.

Overall, the evidence suggests that elevated $\mathrm{HbA} 1 \mathrm{c}$ level is associated with an increased incidence of wound infection in cardiac surgery patients, but it is unclear if there is a specific level of $\mathrm{HbA} 1 \mathrm{c}$ associated with this increased incidence that could serve as a target for pre-operative glycaemic control as studies used a range of $\mathrm{HbA} 1 \mathrm{c}$ cut-offs in their analyses. Yet, further work is required to determine the exact cut-off level and the association between $\mathrm{HbA} 1 \mathrm{c}$ level and non-sternal wound infections.

\section{Cardiovascular Events with Poorly Controlled HbA1c}

Several studies have analysed the relationship between $\mathrm{HbA1c}$ levels and the incidence of cardiovascular events, such as peri-operative myocardial infarction (MI), atrial fibrillation $(\mathrm{AF})$, and low cardiac output syndrome. The majority of literature, including a large retrospective study with nearly 4,000 participants, has demonstrated that the HbA1c level alone cannot be used as a predictor for cardiovascular events ${ }^{[23]}$. By contrast, only one study showed a relationship between $\mathrm{HbA} 1 \mathrm{c}$ and cardiovascular event, which suggested that elevated preoperative $\mathrm{HbA} 1 \mathrm{c}$ may be protective for the development of $\mathrm{AF}^{[30]}$.

The largest cohort study that demonstrated that there was no relationship between the $\mathrm{HbA1c}$ level and cardiovascular events analysed outcomes in 1,461 patients undergoing CABG with or without valvular surgery ${ }^{[25]}$. The study found that there 
Table 4. Summary of clinical outcomes in included studies that showed that the HbA1c level is predictive of post-operative wound infection.

\begin{tabular}{|c|c|c|c|c|}
\hline Study & Study design & $\begin{array}{c}\text { Single/ } \\
\text { Multi-centre }\end{array}$ & Sample size & Main outcomes \\
\hline $\begin{array}{l}\text { Narayan et al. }{ }^{[20]}, \\
2017\end{array}$ & Retrospective & Single centre (India) & 4,678 patients & $\begin{array}{l}\text { - HbA1c } \geq 6.5 \% \text { was found to be associated with } \\
\text { a higher rate of sternal dehiscence }(0.44 \% \\
\text { vs. } 1.27 \%, P=0.002) \text { and deep sternal wound } \\
\text { infection }(0.53 \% \text { vs. } 1.32 \%, P=0.004) \text { compared to } \\
\text { HbA } 1 \mathrm{c}<6.5 \% \\
\text { - Multivariable analysis found that } \mathrm{HbA} 1 \mathrm{c} \geq 6.5 \% \text { is } \\
\text { an independent risk factor for sternal dehiscence } \\
\text { (OR } 2.161,95 \% \mathrm{Cl} 1.008-4.630, P=0.04)\end{array}$ \\
\hline $\begin{array}{l}\text { Subramaniam et } \\
\text { al. }{ }^{[2]}, 2014\end{array}$ & Prospective & Single centre (Israel) & 1,461 patients & $\begin{array}{l}\text { - Rate of deep sternal wound infection was } \\
\text { significantly higher in patients with HbA1c } \\
\geq 6.5 \% \text { than }<6.5 \% \text { ( } 2.2 \% \text { vs. } 0.5 \%, P=0.008)\end{array}$ \\
\hline $\begin{array}{l}\text { Finger et al. }{ }^{[30]}, \\
2017\end{array}$ & Retrospective & Single centre (USA) & 531 patients & $\begin{array}{l}\text { - HbA1c }>7.0 \% \text { was associated with increased risk } \\
\text { of infection compared to patients with } \mathrm{HbA} 1 \mathrm{c} \\
\leq 7.0 \%(10.76 \% \text { vs. } 31.58 \%, P<0.001) \\
\text { - HbA1c }>7.0 \% \text { was associated with increased } \\
\text { risk of sternal wound infection ( } 0.84 \% \text { vs. } 5.26 \% \text {, } \\
P=0.030)\end{array}$ \\
\hline $\begin{array}{l}\text { Gatti et al. }{ }^{[25]}, \\
2016\end{array}$ & Prospective & $\begin{array}{c}\text { Multi-centre } \\
\text { (16 centres across } \\
\text { France, Italy, Germany, } \\
\text { UK, Finland and } \\
\text { Sweden) }\end{array}$ & 114 patients & 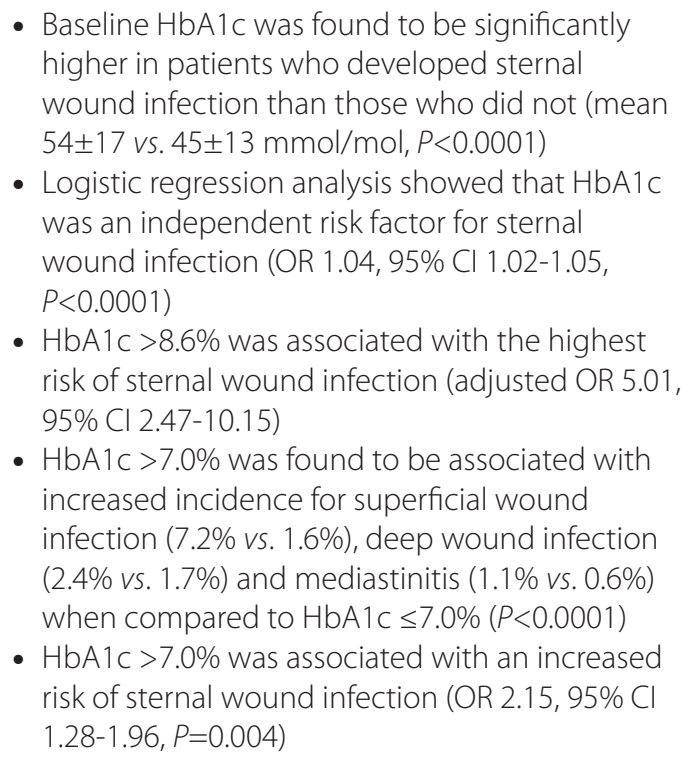 \\
\hline
\end{tabular}

$\mathrm{Cl}=$ confidence interval; $\mathrm{HR}=$ hazard ratio; $\mathrm{OR}=$ odds ratio

was no difference in the incidence of cardiovascular events in patients with $\mathrm{HbA} 1 \mathrm{c}<6.5 \%$ and $>6.5 \%$ : AF $(26.3 \%$ vs. $26.6 \%$, $P=0.90)$, acute $\mathrm{Ml}(0.5 \%$ vs. $0, P=0.333)$ and cardiac tamponade ( 0 vs. $0.2 \%, P=0.313$ ). Other studies similarly showed that there was no significant difference in the incidence of cardiovascular events between patients with high $\mathrm{HbA} 1 \mathrm{c}$ levels and those with normal levels ${ }^{[27,30,32]}$.

Kinoshita et al. ${ }^{[30]}$ carried out a retrospective analysis of 912 patients who underwent isolated CABG. They found that the median $\mathrm{HbA1C}$ was significantly lower in patients who developed AF post-operatively when compared to patients who did not $(5.8 \%, 95 \%$ Cl 5.4-6.3 vs. 6.1\%, 95\% Cl 5.5-7.2, $P=0.01)$. Additionally, results also showed that the incidence of postoperative AF showed a stepwise trend in which the incidence decreased as the HbA1c level decreased: incidence of $28.3 \%$ for patients with $\mathrm{HbA} 1 \mathrm{c} \leq 5.6 \%, 17.4 \%$ for $\mathrm{HbA} 1 \mathrm{c} 5.7-6.7 \%$ and $12.5 \%$ for $\mathrm{HbA} 1 \mathrm{c} 6.8-11.4 \%$ ( $P=0.01$ ). These findings suggest that high $\mathrm{HbA1c}$ levels may be associated with a lower risk of postoperative $A F$, but this is a single retrospective study carried out in Japanese patients, thereby limiting the generality of findings and cannot be used as a sole evidence to support this clinical outcome in the general population. 


\section{HbA1c and Cerebrovascular Accident}

Cerebrovascular accident (CVA) is a severe complication following CABG surgery. CVA indicates whether a patient had a stroke (acute neurological deficit lasting more than 24 hours) or a transient ischemic attack (TIA) (deficit resolving within 24 hours). The meta-analysis by Zheng et al. assessed the effect of $\mathrm{HbA} 1 \mathrm{c}$ levels and CVA among diabetic patients $(n=4,356)$ undergoing CABG surgery ${ }^{[31]}$. Their analysis, which included five studies ${ }^{[18,22,31-33]}$, indicated that $\mathrm{HbA} 1 \mathrm{c}$ levels were directly correlated with the risk of stroke after CABG surgery (OR 2.07, 95\% Cl 1.29-3.32, $P=0.003)$, with very low heterogeneity $\left(I^{2}=0 \%, P=0.42\right)$. Only one retrospective study significantly indicated a possible role for $\mathrm{HbA} 1 \mathrm{c}$ in predicting stroke outcomes ${ }^{[18]}$. This retrospective study had a comparatively large sample size $(n=3,089)$, hence sufficient power to solely elucidate an association between $\mathrm{HbA1c}$ levels and stroke. The study indicated that patients with $\mathrm{HbA1c}$ values of $7.6 \%$ or more have adjusted odds of CVA 2.23 (1.06-4.70) times higher than patients with values below this threshold. The overall incidence of stroke for all patients was very low (1.7\%). Other studies were either contradictory ${ }^{[31,32]}$ or inconclusive ${ }^{[22,33]}$ due to small sample sizes and inherent low incidence of stroke.

However, a larger and more recent meta-analysis $(n=5,381)$ conducted by Wang et al. ${ }^{[34]}$ showed that there was no significant difference in stroke incidence between diabetic patients with lower pre-operative $\mathrm{HbA} 1 \mathrm{c}$ levels and those with higher preoperative $\mathrm{HbA} 1 \mathrm{c}$ levels after CABG and $\mathrm{PCl}(\mathrm{OR} 1.49,95 \% \mathrm{Cl} 0.94-$ 2.37, $P=0.37$, and $\mathrm{I}^{2}=8 \%$ ). Higher $\mathrm{HbA} 1 \mathrm{c}$ levels were defined as pre-operative $\mathrm{HbA} 1 \mathrm{c} \geq 6.5 \%$ or $7 \%$ and lower $\mathrm{HbA} 1 \mathrm{c}$ levels as pre-operative $\mathrm{HbA} 1 \mathrm{c}<6.5 \%$ or $7 \%$.

Interestingly, Biskupski et al. ${ }^{[28]}$ noted that TIAs were more common in patients with $\mathrm{HbA} 1 \mathrm{c}<7 \%$, while strokes were significantly more common in patients with decompensated diabetes ( $\mathrm{HbA} 1 \mathrm{c}<7 \%$ vs. HbA1c $>8 \%, P=0.04)$. Current research indicates a potential association between the baseline risk of TIA events and exposure to hypoglycaemia ${ }^{[35,36]}$.

\section{HbA1c and Renal Failure}

A recent prospective study reported that acute renal failure is one of the most common post-CABG complications in diabetic patients ${ }^{[36]}$. Compared with diabetic patients with $\mathrm{HbA} 1 \mathrm{c} \leq 7 \%$, those with $\mathrm{HbA} 1 \mathrm{c}>7 \%$ had more incidence of renal failure (10\% vs. $0 \%{ }^{[33]}$. Additionally, the results of a recent meta-analysis, involving nine studies $(n=5,858)$, suggested that a higher pre-operative $\mathrm{HbA1c}$ level was associated with a high risk of renal failure after cardiac surgery $\left(\mathrm{OR}=1.63,95 \% \mathrm{Cl} 1.13-2.33, P=0.47\right.$, and $\left.\mathrm{I}^{2}=0 \%\right)$ [34]. Furthermore, by using receiver operating characteristic value thresholds, Halkos et al. ${ }^{[18]}$ showed that renal failure occurred more commonly in patients with elevated HbA1c (threshold 6.7, OR 2.1). It is worth noting that the $6.7 \%$ threshold derived is below the $7 \%$ glycaemic target of the American Diabetes Association ${ }^{[14]}$.

\section{HbA1c and Prolonged Hospital Stay}

There are differences between studies in the definition of a prolonged hospital stay (from $\geq 3$ to 14 days) ${ }^{[37,38]}$, which sheds an interesting light on the association between $\mathrm{HbA1}$ c and hospital length of stay (LOS).
In a retrospective study ( $\mathrm{n}=570)$, extended LOS was defined as $>3$ days ${ }^{[11]}$. The authors found that $\mathrm{HbA1c}$ was an independent predictor of hospital stay, regardless of blood sugar levels ( $P=0.001)$. Moreover, Medhi et al. ${ }^{[37]}$ found similar results of LOS in 135 patients who underwent coronary artery bypass surgery; $\mathrm{HbA} 1 \mathrm{c} \geq 7 \%$ was found to be a strong predictor of $L O S \geq 6$ days ( $P=0.025$ ). However, interestingly, when defining prolonged LOS as $\geq 14$ days, LOS was not affected by pre-operative HbA1c levels (with a cut-off of $\mathrm{HbA} 1 \mathrm{c}=7 \%$ for optimal and suboptimal levels, $P=0.367)^{[38]}$.

It is noted that, in diabetic patients undergoing CABG, HbA1c levels significantly correlated with post-operative LOS. Patients with suboptimal medium-term glycaemic control ( $\mathrm{HbA} 1 \mathrm{c}>7 \%$, $\mathrm{n}=38$ ) had longer LOS than patients with optimal medium-term glycaemic control ( $\mathrm{HbA} 1 \mathrm{c} \leq 7 \%, \mathrm{n}=57)$ (mean post-operative LOS 6 days vs. 7.5 days; post-operative LOS mean rank: 32 days vs. 46 days; $P=0.008)^{[33]}$.

The meta-analysis of five studies $(n=3,002)$ conducted by Wang et al. ${ }^{[34]}$ reported a higher pre-operative $\mathrm{HbA} 1 \mathrm{c}$ level resulted in a 1.08-day mean increase in hospital stay after cardiac surgery (WMD=1.08, 95\% Cl 0.46-1.71).

On the other hand, intensive care stay was not affected by the level of $\mathrm{HbA} 1 \mathrm{c}$, as several studies reported no significant difference in intensive care unit days between patients with lower pre-operative $\mathrm{HbA} 1 \mathrm{c}$ levels and those with higher $\mathrm{HbA1c}$ levels after cardiac surgery $[27,32,34,40]$.

\section{Summary}

Despite conflicting clinical evidence on higher $\mathrm{HbA1c}$ as a prognostic marker of poor outcomes after cardiac surgery, there is universal consensus of possible underlying mechanism of association. Therefore, future research is needed to further elucidate any possible clinical association is warranted. Such research has the potential to improve cardiac surgery clinical practice guidelines.

$\mathrm{HbA1c}$ has a significant role in inducing dyslipidaemia, hyperhomocysteinemia, hypertension and increased C-reactive protein, oxidative stress, and blood viscosity ${ }^{[11]}$. Cardiac surgery, stress, and anaesthesia can exacerbate oxidative stress and increase blood viscosity, thereby perpetuating the effect of high $\mathrm{HbA1C}$ in patients with diabetes and the likelihood of devolvement of cardiovascular event ${ }^{[41]}$. Increased blood viscosity of diabetic patients, leading to blood clots, can precipitate acute $\mathrm{MI}^{[42]}$. Moreover, high HbA1c can cause vascular endothelial cell damage due to shear stress from blood flow, with increased cellular proliferation ${ }^{[12]}$, which can cause $\mathrm{Ml}$ and stroke after coronary artery stenting ${ }^{[43]}$. Chronic hyperglycaemia-induced dysmetabolism weakens chemokine chemotaxis and decreases immune function in patients with diabetes ${ }^{[43]}$. This increases the likelihood of wound infection after cardiac surgery and increases collateral tissue damage upon infection. For these reasons, high pre-operative $\mathrm{HbA1c}$ levels may be predictive of a prolonged post-operative hospital stay.

\section{Future Directions}

In this review, we have discussed both retrospective and prospective studies that have looked at $\mathrm{HbA} 1 \mathrm{c}$ as a predictor 
of various post-operative adverse outcomes. However, most of these studies had small sample sizes, thus, from the onset, limited ability to draw statistically meaningful conclusions about adverse outcomes of inherently low event rates in any cohort; reduced statistical power and possible type II statistical error. Moreover, studies have used different cut-off values of pre-operative HbA1c levels, such as 6.5\%,7\%, 7.5\%, and 8\%. Further research should be directed at determining a pre-operative cut-off of 'suboptimal glycaemic control' for pre-operative optimisation clinical guidelines of the surgical patient.

A recent retrospective study by Kim et al. ${ }^{[19]}$ of 703 patients with diabetes mellitus who underwent off-pump coronary artery bypass surgery (OPCAB) provides the strongest evidence to date of the prognostic role of $\mathrm{HbAlc}$. The use of composite postoperative morbidity and mortality (CMM) endpoints (permanent stroke, prolonged ventilation, deep sternal wound infection, renal failure, reoperation, and 30-day mortality) attenuates the prospect of a misleading statistical conclusion by combining adverse events of low incidence. Kim et al. ${ }^{[19]}$ found that the incidence of $\mathrm{CMM}$ endpoints was greater in patients with $\mathrm{HbA} 1 \mathrm{C} \geq 7.0 \%$ ( $21 \%$ vs. $15 \%, P=0.041$ ). Moreover, receiver operator characteristic curve analysis revealed $\mathrm{HbA} 1 \mathrm{c} 7.85 \%$ as the optimal threshold for CMM endpoints (area under the curve 0.556, 95\% Cl 0.501-0.611, $P=0.048$ ). This study has provided rationale for future prospective studies with sufficient power to examine whether postponing cardiac surgery in patients with high pre-operative $\mathrm{HbA} 1 \mathrm{c}$ levels would improve post-operative outcomes.

Moreover, Kim et al. ${ }^{[19]}$ indicated that a high pre-operative HbA1c ( $27.0 \%)$ level alone, and not the variables related to perioperative glycaemic control, was independently associated with adverse outcome in diabetic patients undergoing OPCAB, although high $\mathrm{HbA} 1 \mathrm{c}$ levels contributed to greater perioperative glycaemic variability. However, a randomised controlled trial conducted by Bláha et al. ${ }^{[44]}$ suggested that it is cardiac surgery patients with previously undiagnosed diabetes who have the worst prognosis. Comparable conclusion was suggested in noncardiac studies ${ }^{[45,46]}$. Recent studies have shown that perioperative intravenous insulin infusion is more frequently administered in known diabetics due to more frequent monitoring of their capillary glucose concentrations ${ }^{[19,47]}$. However, despite more frequently administered insulin in the high HbA1c group, adverse outcomes remained more prevalent in this group compared to normal $\mathrm{HbA} 1 \mathrm{c}$ group, thereby further attenuating the prognostic role of $\mathrm{HbA} 1 \mathrm{c}$. Nevertheless, optimisation of preoperative $\mathrm{HbA} 1 \mathrm{c}$ concentrations with a combined intravenous and subcutaneous insulin glucose has been shown to reduce surgical mortality and morbidity in diabetic patients undergoing cardiac surgery ${ }^{[48]}$

Future research should be directed at the determining the optimal level of perioperative glycaemic management and the crucial perioperative period to maintain this $\mathrm{HbA1c}$ level. Although there are current ongoing outcome studies currently in this area (e.g. the Optimising Cardiac Surgery outcomes in People with diabetes (OCTOPUS) trial - protocol number HTA16/25/12), there remain few data on the outcomes and effects of intervention on those who are not known to have diabetes ${ }^{[49-51]}$.

\section{CONCLUSION}

The cohorts of patients undergoing cardiac surgery are shifting to a higher risk than a decade ago, with more diabetes and other comorbidities; therefore, poorly controlled diabetes and deranged pre-operative HbA1c can have a detrimental effect on outcomes after cardiac surgery and significantly affect morbidity. Optimum peri-operative diabetes control can help to minimize post-operative complications.

\section{No financial support. \\ No conflicts of interest.}

\section{REFERENCES}

1. Nathan DM, Turgeon H, Regan S. Relationship between glycated haemoglobin levels and mean glucose levels over time. Diabetologia. 2007;50(11):2239-44. doi:10.1007/s00125-007-0803-0.

2. International Expert Committee. International expert committee report on the role of the A1C assay in the diagnosis of diabetes. Diabetes Care. 2009;32(7):1327-34. doi:10.2337/dc09-9033.

3. Zheng J, Cheng J, Wang T, Zhang Q, Xiao X. Does HbA1C level have clinical implications in diabetic patients undergoing coronary artery bypass grafting? A systematic review and meta-analysis. Int J Endocrinol. 2017;2017:1537213. doi:10.1155/2017/1537213.

4. Yong PH, Weinberg L, Torkamani N, Churilov L, Robbins RJ, Ma R, et al. The presence of diabetes and higher $\mathrm{HbA} 1 \mathrm{c}$ are independently associated with adverse outcomes after surgery. Diabetes Care. 2018;41 (6):1172-9. doi:10.2337/dc17-2304. 
5. American Diabetes Association. Diagnosis and classification of diabetes mellitus. Diabetes Care. 2014;37 Suppl 1:S81-90. doi:10.2337/dc14-S081.

6. Bunn HF, Haney DN, Kamin S, Gabbay KH, Gallop PM. The biosynthesis of human hemoglobin A1c. Slow glycosylation of hemoglobin in vivo. J Clin Invest. 1976;57(6):1652-9. doi:10.1172/JCl108436.

7. Welsh KJ, Kirkman MS, Sacks DB. Role of glycated proteins in the diagnosis and management of diabetes: research gaps and future directions. Diabetes Care. 2016;39(8):1299-306. doi:10.2337/dc15-2727.

8. Sherwani SI, Khan HA, Ekhzaimy A, Masood A, Sakharkar MK. Significance of HbA1c test in diagnosis and prognosis of diabetic patients. Biomark Insights. 2016;11:95-104. doi:10.4137/BMI.S38440.

9. Higgins PJ, Bunn HF. Kinetic analysis of the nonenzymatic glycosylation of hemoglobin. J Biol Chem. 1981;256(10):5204-8.

10. Goldin A, Beckman JA, Schmidt AM, Creager MA. Advanced glycation end products: sparking the development of diabetic vascular injury. Circulation. 2006;114(6):597-605. doi:10.1161/ CIRCULATIONAHA.106.621854.

11. Jarolim P, Lahav M, Liu SC, Palek J. Effect of hemoglobin oxidation products on the stability of red cell membrane skeletons and the associations of skeletal proteins: correlation with a release of hemin. Blood. 1990;76(10):2125-31.

12. LiYS, Haga JH, Chien S. Molecular basis of the effects of shear stress on vascular endothelial cells. J Biomech. 2005;38(10):1949-71. doi:10.1016/j. jbiomech.2004.09.030.

13. Use of glycated haemoglobin ( $\mathrm{HbA1c}$ ) in the diagnosis of diabetes mellitus: abbreviated report of a WHO consultation. Geneva: World Health Organization; 2011.

14. American Diabetes Association. 6. Glycemic targets: standards of medical care in diabetes-2020. Diabetes Care. 2020;43(Suppl 1):S66-S76. doi:10.2337/dc20-S006.

15. Ditzel J, Kjaergaard J. Haemoglobin Alc concentrations after initial insulin treatment for newly discovered diabetes. Br Med J. 1978;1 (6115):741-2. doi:10.1136/bmj.1.6115.741.

16. McGinn JT Jr, Shariff MA, Bhat TM, Azab B, Molloy WJ, Quattrocchi $E$, et al. Prevalence of dysglycemia among coronary artery bypass surgery patients with no previous diabetic history. J Cardiothorac Surg. 2011;6:104. doi:10.1186/1749-8090-6-104.

17. Kuhl J, Sartipy U, Eliasson B, Nyström T, Holzmann MJ. Relationship between preoperative hemoglobin A1 c levels and long-term mortality after coronary artery bypass grafting in patients with type 2 diabetes mellitus. Int J Cardiol. 2016;202:291-6. doi:10.1016/j.ijcard.2015.09.008.

18. Halkos ME, Puskas JD, Lattouf OM, Kilgo P, Kerendi F, Song HK, et al. Elevated preoperative hemoglobin A1c level is predictive of adverse events after coronary artery bypass surgery. J Thorac Cardiovasc Surg. 2008;136(3):631-40. doi:10.1016/j.jtcvs.2008.02.091.

19. Kim HJ, Shim JK, Youn YN, Song JW, Lee H, Kwak YL. Influence of preoperative hemoglobin A1c on early outcomes in patients with diabetes mellitus undergoing off-pump coronary artery bypass surgery. J Thorac Cardiovasc Surg. 2020;159(2):568-76. doi:10.1016/j. jtcvs.2019.01.086.

20. Narayan P, Kshirsagar SN, Mandal CK, Ghorai PA, Rao YM, Das D, et al. Preoperative glycosylated hemoglobin: a risk factor for patients undergoing coronary artery bypass. Ann Thorac Surg. 2017;104(2):60612. doi:10.1016/j.athoracsur.2016.12.020.

21. van den Boom W, Schroeder RA, Manning MW, Setji TL, Fiestan GO, Dunson DB. Effect of A1C and glucose on postoperative mortality in noncardiac and cardiac surgeries. Diabetes Care. 2018;41(4):782-8. doi:10.2337/dc17-2232.

22. Tsuruta R, Miyauchi K, Yamamoto T, Dohi S, Tambara K, Dohi T, et al.
Effect of preoperative hemoglobin A1 c levels on long-term outcomes for diabetic patients after off-pump coronary artery bypass grafting. J Cardiol. 2011;57(2):181-6. doi:10.1016/j.jjcc.2010.11.003.

23. Ramadan M, Abdelgawad A, Elshemy A, Sarawy E, Emad A, Mazen M, et al. Impact of elevated glycosylated hemoglobin on hospital outcome and 1 year survival of primary isolated coronary artery bypass grafting patients. Egypt Heart J. 2018;70(2):113-8. doi:10.1016/j.ehj.2017.09.002.

24. Subramaniam B, Lerner A, Novack V, Khabbaz K, Paryente-Wiesmann $M$, Hess $P$, et al. Increased glycemic variability in patients with elevated preoperative $\mathrm{HbA} 1 \mathrm{C}$ predicts adverse outcomes following coronary artery bypass grafting surgery. Anesth Analg. 2014;118(2):277-87. doi:10.1213/ANE.0000000000000100.n.24

25. Gatti G, Perrotti A, Reichart D, Maschietto L, Onorati F, Chocron S, et al. Glycated hemoglobin and risk of sternal wound infection after isolated coronary surgery. Circ J. 2016;81 (1):36-43. doi:10.1253/circj.CJ-16-0778. n. 25

26. Kinoshita T, Asai T, Suzuki T, Kambara A, Matsubayashi K. Preoperative hemoglobin A1c predicts atrial fibrillation after off-pump coronary bypass surgery. Eur J Cardiothorac Surg. 2012;41(1):102-7. doi:10.1016/j. ejcts.2011.04.011.n.26

27. Göksedef D, Ömeroğlu S, Yalvaç E, Bitargil M, Ipek G. Is elevated HbA1c a risk factor for infection after coronary artery bypass grafting surgery? Turk J Thorac Cardiovasc Surg. 2010;18(4): 252-8.n.27

28. Biskupski A, Waligórski S, Kowalik B, Żych A, Sielicki P, Mirecki O, et al. Glycated hemoglobin $\mathrm{HbA1c}$ - a new risk marker for the outcome of cardiac surgery? Kardiochir Torakochirurgia Pol. 2014;11(1):7-11. doi:10.5114/kitp.2014.41922. n.28

29. Strahan S, Harvey RM, Campbell-Lloyd A, Beller E, Mundy J, Shah P. Diabetic control and coronary artery bypass: effect on shortterm outcomes. Asian Cardiovasc Thorac Ann. 2013;21(3):281-7. doi:10.1177/0218492312451983.

30. Finger B, Brase J, He J, Gibson WJ, Wirtz K, Flynn BC. Elevated hemoglobin $\mathrm{A} 1 \mathrm{C}$ is associated with lower socioeconomic position and increased postoperative infections and longer hospital stay after cardiac surgical procedures. Ann Thorac Surg. 2017;103(1):145-51. doi:10.1016/j. athoracsur.2016.05.092.

31. Sato H, Carvalho G, Sato T, Lattermann R, Matsukawa T, SchrickerT. The association of preoperative glycemic control, intraoperative insulin sensitivity, and outcomes after cardiac surgery. J Clin Endocrinol Metab. 2010;95(9):4338-44. doi:10.1210/jc.2010-0135.

32. Knapik P, Cieśla D, Filipiak K, Knapik M, Zembala M. Prevalence and clinical significance of elevated preoperative glycosylated hemoglobin in diabetic patients scheduled for coronary artery surgery. Eur J Cardiothorac Surg. 2011;39(4):484-9. doi:10.1016/j.ejcts.2010.07.037.

33. Santos JM, Favaloro RR, Lowenstein D, Sanabria H, Raffaelli H, Hershson A. Medium-term glycemic control in diabetics before coronary bypass surgery. Medicina (B Aires). 2015;75(5):277-81.

34. Wang J, Luo X, Jin X, Lv M, Li X, Dou J, et al. Effects of preoperative HbA1C levels on the postoperative outcomes of coronary artery disease surgical treatment in patients with diabetes mellitus and nondiabetic patients: a systematic review and meta-analysis. J Diabetes Res. 2020;2020:3547491. doi:10.1155/2020/3547491.

35. Gitt AK, Bramlage P, Binz C, Krekler M, Deeg E, Tschöpe D. Prognostic implications of DPP-4 inhibitor vs. sulfonylurea use on top of metformin in a real world setting - results of the 1 year follow-up of the prospective DiaRegis registry. Int J Clin Pract. 2013;67(10):1005-14. doi:10.1111/ ijcp.12179.

36. Rathmann W, Kostev K, Gruenberger JB, Dworak M, Bader G, Giani G. Treatment persistence, hypoglycaemia and clinical outcomes in 
type 2 diabetes patients with dipeptidyl peptidase-4 inhibitors and sulphonylureas: a primary care database analysis. Diabetes Obes Metab. 2013;15(1):55-61. doi:10.1111/j.1463-1326.2012.01674.x.

37. Medhi M, Marshall MC Jr, Burke HB, Hasan R, Nayak D, Reed G, et al. HbA1C predicts length of stay in patients admitted for coronary artery bypass surgery. Heart Dis. 2001;3(2):77-9. doi:10.1097/00132580-20010300000003.

38. Almogati JG, Ahmed EO. Glycated hemoglobin as a predictor of the length of hospital stay in patients following coronary bypass graft surgery in the Saudi population. Braz J Cardiovasc Surg. 2019;34(1):28-32. doi:10.21470/1678-9741-2018-0202.

39. Arslan Ü, Memetoğlu ME, Kutlu R, Erbasan O, Tort M, Yildiz E, et al. Preoperative Hba1c level in prediction of short-term morbidity and mortality outcomes following coronary artery bypass grafting surgery. Russ Open Med J. 2015;4(2):204. doi:10.15275/rusomj.2015.0204.

40. Romano E Silva AC, Dias GM, de Carvalho JJ, De Lorenzo A, Kasal DAB. Research proposal: inflammation and oxidative stress in coronary artery bypass surgery graft: comparison between diabetic and non-diabetic patients. BMC Res Notes. 2018;11(1):635. doi:10.1186/s13104-018-37435.

41. Kosiborod M, Inzucchi SE, Krumholz HM, Xiao L, Jones PG, Fiske S, et al. Glucometrics in patients hospitalized with acute myocardial infarction: defining the optimal outcomes-based measure of risk. Circulation. 2008;117(8):1018-27. doi:10.1161/CIRCULATIONAHA.107.740498.

42. Kassaian SE, Goodarzynejad H, Boroumand MA, Salarifar M, Masoudkabir F, Mohajeri-Tehrani MR, et al. Glycosylated hemoglobin (HbA1c) levels and clinical outcomes in diabetic patients following coronary artery stenting. Cardiovasc Diabetol. 2012;11:82. doi:10.1186/1475-2840-11-82.

43. Moura J, Madureira P, Leal EC, Fonseca AC, Carvalho E. Immune aging in diabetes and its implications in wound healing. Clin Immunol. 2019;200:43-54. doi:10.1016/j.clim.2019.02.002.

44. Bláha J, Mráz $M$, Kopecký P, Stříteský M, Lipš M, Matias $M$, et al.
Perioperative tight glucose control reduces postoperative adverse events in nondiabetic cardiac surgery patients. J Clin Endocrinol Metab. 2015;100(8):3081-9. doi:10.1210/jc.2015-1959.

45. Frisch A, Chandra P, Smiley D, Peng L, Rizzo M, Gatcliffe C, et al. Prevalence and clinical outcome of hyperglycemia in the perioperative period in noncardiac surgery. Diabetes Care. 2010;33(8):1783-8. doi:10.2337/ dc10-0304.

46. Kotagal M, Symons RG, Hirsch IB, Umpierrez GE, Dellinger EP, Farrokhi $E T$, et al. Perioperative hyperglycemia and risk of adverse events among patients with and without diabetes. Ann Surg. 2015;261(1):97-103. doi:10.1097/SLA.0000000000000688.

47. Jones CE, Graham LA, Morris MS, Richman JS, Hollis RH, Wahl TS, et al. Association between preoperative hemoglobin A1c levels, postoperative hyperglycemia, and readmissions following gastrointestinal surgery. JAMA Surg. 2017;152(11):1031-8. Erratum in: JAMA Surg. 2018;153(8):782. doi:10.1001/jamasurg.2017.2350.

48. Schmeltz LR, DeSantis AJ, Thiyagarajan V, Schmidt K, O'Shea-Mahler E, Johnson D, et al. Reduction of surgical mortality and morbidity in diabetic patients undergoing cardiac surgery with a combined intravenous and subcutaneous insulin glucose management strategy. Diabetes Care. 2007;30(4):823-8. doi:10.2337/dc06-2184.

49. Levy N, Dhatariya K. Pre-operative optimisation of the surgical patient with diagnosed and undiagnosed diabetes: a practical review. Anaesthesia. 2019;74 Suppl 1:58-66. doi:10.1111/anae.14510.

50. Leung MST, Lin SG, Uthayanan L, Harky A. Effects of antidiabetic medications on cardiovascular outcomes. J Card Surg. 2020 Oct;35(10):2759-2767. doi: 10.1111/jocs.14709. Epub 2020 Sep 16. PMID: 32939829.

51. O'Neill P, Leung MST, Visser RAB, Harky A. Diabetic Control Agents and Their Impact on Cardiac Surgery Patients: A Clinical Overview. J Cardiovasc Pharmacol Ther. 2020 Nov 23:1074248420963688. doi: 10.1177/1074248420963688. Epub ahead of print. PMID: 33226267. 